\title{
THE PRESENT POSITION OF THE SEWAGE PROBLEM.
}

By TV. KAIE PARRY, M.A., M.Inst.C.E. F.R.I.B.A.

(FELlow.)

NOTHING illustrates more forcibly the complexity of the sewage problem than the history of the last six years.

At the Congress of The Sanitary Institute held in Leels in 1887, a group of papers was reat, each of which had a direct bearing upon the sewage purification question. In the discussion which followed, one of the speakers, with a pardonable touch of sarcasm, remarked that ther were fortunate in getting that morning from the authors of these papers no fewer than three complete solutions of the sewage problem.

Six years of added experience have not sufficed to convince the author that the principles which he then ventured to enunciate were erroneous or contrary to the teachings of science, nor does it appear to him that they were extravagant or utopian, but he is free to admit that the methods, the use of which he advocated, have not found general acceptance.

On the same occusion Mr. Libdin read a paper" on "The Scientitic Basis of Sewage Treatment." After sketching briefly the systems which had been in use prior to the introcluction of the bacteriological methods, he added that in the earlier systems a clear effuent was produced with which it was possible to cleal, but that the sludge still remained the bete noive of all those concerned in sewage clisposal. He then gave an outline of the two most recent alternative methods for the purification of sewage, one of which was based upon the use of ärobic bacteria only, and the other upon the use of anä̈robic organisms for the preliminary stage, followed by the utilization of aerrobic bacteria for the final purification of the liquici. Into the relative merits of the two mothods he did not enter, but he stated with great definiteness that both systems had proved highly satisfactory in practice, and both removed once and for all the troubles of sludge disposal. 
Mr. Donald Cameron contributed at the same Congress a most interesting account of results achieved by the preliminary treatment of sewage by anaïrobic bacteria in a suitably constructed tank prior to the passage of the liquid on to the bacteria beds. $\mathrm{Mr}_{\mathrm{r}}$. Cameron very wisely refrained from making prophecies, but he stated that the analyses of Messrs. Dibdin and Thudichum showed that at Exeter 81 per cent. of the total suspended matter in the sewage which passed through the tank had disappeared or been lost. In other worls, that by the action of anaërobic bacteria four-fifths of the suspended solids in the sewage was digested and thus finally disposed of.

In 1898, at the Congress in Birmingham, Mr. Dibdin spoke very confidently about the economies which would result from the new system of sewage treatment. He stated that he was satisfied that the day would come when the introduction of the bacteriological system would be the means of effecting an enormous saving to the country generally. They saved in London, Mr. Dibdin added, ten or twelve millions, and there was a town not far from where they were then meeting that would probably save half a million. If they alded that sum to the capitalised value of the reduced expenses of working the comntry would benefit enormously. In making this statement Mr. Dibdin assured his hearers ho was speaking from the ratepayer's' point of view. These assurances must have led his hearers to believe that not only would the working expenses attendant upon the adoption of bacteriological processes be very much less than those of the olider methods of sewage treatment, but that the actual cost of constructing works suitable for the proposed methods would be very much less than the outlays necessitated by the adoption of chemical systems.

In Southampton, in 1899, the author reasserted the opinion that le had expressed in Leeds, that in every system of sewage treatment there must be some residuum which, if it were not removed, would sooner or later clog the bacteria beds, whereas if it were removed it would constitute sludge which must be handled and disposed of. Referring to the Barking experiments, where it was alleged that one acre of beds could successfully treat one million gallons of liquid per day, the author asserted that notwithstanding these confident assertions, he still believed that at least two acres of beds were necessary to treat a million gallons a day. He estimated the cost of constructing these beds under favourable circumstances at $£ 2,000$ per acre, and added that the cost would of ten greatly exceed this amount.

In the discussion, Mr. Thudichum asserted that under farourable 
circumstances the beds could be constructed for $£ 700$ per acre, and this, he adderl, was fact and not theory.

At a Sessional Meeting of the Institute in 1901, Dr. Kenwood and Dr. Butler read an admirable paper on the then position of the sewage problem. In this paper the authors approached the question calmly and dispassionately, and they gave a most instructive resume of the results of their joint researches. Referring to the advantages attendant upon the passage of sewage through tanks prior to its introduction into the bacteria beds, they stated that they found that by the use of such tanks from 30 to 40 per cent. of the total suspended solids could be digested.

They emphasised the importance of sufficient tank capacity, and they appeared to consider that the best results were attained when the tank capacity was sufficient to give a rest of 36 to 48 hours.

This calculation led the author to observe, in the discussion which ensued, that if engineers were to be called upon to provide tanks on such a liberal scale the works would become very costly, as storage capacity was a serious item in connection with the expenditure on sewage works, and in the end the system which did the best work in the most economical way was the one which must take first place.

The foregoing is an epitome of the views and opinions expressed by some of those who had interested themselves in the developments of the sewage problem, which were the outcome of the advent of the bacteriological systems, in so far as they related to the two aspects of the question which more particularly appealed to the practical engineer. These two aspects were (1) the extent to which the adoption of the system would overcome the sludge difficulty and (2) the economic value of such a system from the point of view of the ratepayer.

No cloubt to the scientific mind the mere matter of cost is not an attractive or supremely-important consideration compared with the possibility of achieving success by the production of an effluent which would leave nothing to be desired in the eyes of the chemist or the bacteriologist. But the author's lot is cast in a poor comtry, where ratepayers are neither able or willing to embark upon great works except under the most strenuous compulsion, and perhaps for this reason he has been obliged to examine very carefully the grounds upon which works of magnitude for sewage treatment can reasonably be imposed upon the struggling shopkeepers and others who constitute the urban population of the smaller towns and villages in Ireland.

Hence it is that the facts and figures which have come to light duringr the last two years have given additional food for reflection, and must have 
proved both startling and somewhat disconcerting to some of those who prophesied so contidently before their publication. Up to 1901 it would really almost seem as if the chemists and bacteriologists thought they were ushering in the Millennium and that only a little more time was needed to demonstrate, even to the mind of an ill-informed sceptic, that, whaterer the future had in store, the possibility of reaction in the methods of sewage treatment was scarcely conceivable.

From this point of view the papers contributed to the Manchester Congress in 1902 by Mr. G. H. Fowler and M. J. P. Wilkinson are singularly instructice. In these papers will be found a great accumulation of valuable information, the direct results of very extended operations, both experimental and permanent, in landling the sewage of a large manufacturing centre. The new works at Manchester which are so fully and lucidly explained and illustrated in Mr. Wilkinson's paper are the outcome of these experiments. We are informed that these works will cost, in round figures, half a million of money, and they are capable of dealing, by double contact, with a dicily flow of 63 million gallons and also of treating less completely on stom water filters, a further quantity equal to another 63 million gallons, making a total maximum capacity in wet weather of 126 million gallons per day.

Assuming that the suggestions made by the Local Govermment Board were aclopted, namely, that sewage works of this character should have a capacity sufficient to enable them to treat a quantity equal to three times the dry weather flow completely by contact beds, and a further quantity equal also to three times the clry weather flow partially on storm water filters, then the Manchester works can only be considered capable of satisfactorily dealing with a volume of sewage representing a dry weather flow of 21,000,000 gallons per clay. If we take the standard usually adopted by engineers, namely, 30 gallons per head per day as the average dry weather flow, then it would appear that those works are not more than sufficient for a population of seven hundred thousand persons. In other words the expenditure necessitated by similar works on the same scale for a population of one million would be almost $£ 700,000$, and the actual cost would work out at 13s. 10d. per head.

In the face of these figures, is anyone still prepared to contend that the introduction of bacteriological systems will be the means of effecting an enormous saving to the country generally?

Turning to the sludge question Mr. Fowler stated that with a tank space equal to half the daily flow of Manchester sewage it is possible to digest about 25 per cent. of the total suspended matter in the sewage. 
With this figure before him is Mr. Dibdin prepared to athere to the statement which he made at Leeds that both the airrobic and the anaërobic systems of biological treatment of sewage "remore once and for all the troubles of sludge clisposal."

Have not six years' experience justified the opinion expressed on the same day in Leeds by the author that with avcrage town sewage it was not possible to have sewage works without sewage sludgre, and that whilst it might be possible to reduce tlic quantity of sludge to a minimum, the day was far distant when it would disappear altogether.

But fortunately we are not by any means dependent upon the reports of the Manchester experts alone for our present knowledge.

The seconl report of the Commissioners of the Sewage Commission is in our hands, and we can here find emborlied the views of some of the distinguisher men who are now engaged upon this enquiry.

Professor Boyce contributes a critical essay upon the treatment of Manchester sewage by bacteria beds which should be studied by all those who wish to master the subject. Among other statements attention may be drawn to the following:-

1. That the purification attendant upon the destruction of organic matter in the beds is effected "at the expense of a gradual reduction of capacity in the bed." If this be true, then, the life of the bed is a finite "quantity, and the question of renewal of the material must somer or later he faced.

2. That the working of the septic tank must be as carefully watched and regulated as the contact bed, or otherwise a large amount of suspencled sludge passes over.

3. Professor Borce asks and answers the question, "Can the addition of chemicals before bacterial treatment be dispensed with?" In reply to this, he points out that the report of the experts on the Manchester sewage was against the use of chemical precipitation. This report was, however, based upon the assumption that the beils would get rid of the sludge difficulty. "At Chorley," he adds, "we demonstrated by a long series of experiments how efficacious thorough chemical precipitation followed by filtration may be, and we brought to the notice of the Commission similar processes in use in Germany. It is," he adds, "a question of expense. If the septic process is used, sludge will still accumulate, and will require to be removed."

When the author in 1898 , at Southampton, read a paper on "Sewage Purification without Filtration," he described the methods advocated by $\mathrm{D}_{1}$. Adeney for treating sewage by precipitation followed by the introduc- 
tion of an oxygen-carrying compound into the liquid; he submitted that excellent results had been achieved in this way as well as by the use of bacteria beds, and he added that if this be true, "the controversy will then resolve itself into a mere question of relative cost." He suggested that " it would appear to be preferable to face the cost and inconvenience of some preliminary treatment for the purpose of separating the solids day by day, rather than to run the risk of filling up the voids in the beds, as the periodical renewal of the material would entail a serious charge on the rates."

Even those who are not clisposed to accept this opinion will at all events have to admit that the author in 1898, was at least as near to the truth as those who ridiculed his views as not being abreast of modern research.

Time does not admit of anything more than a cursory reference to Dr. McGowan's report, which follows that of Professor Boyce, but two of his observations are of particular interest to the Engineer.

The first is that if on a small bed the sicles are sloped so that the superficial area at the top of the bed is $3 \frac{1}{2}$ times greater than that at the bottom of the bed the rerating conditions must be more farourable than in a large bed where the relative areas cannot be in the same proportion. It is, perhaps, scarcely necessary to point out that beds of the size and shape which Dr. McGowan prefers would be relatively much more costly than the larger beds.

Secondly, Dr. McGowan expressed the opinion that the "life" of an open septic tank under ordinary conditions has still to be determined.

These few notes would be manifestly incomplete without some reference to Dr. Clowes' fourth report to the London County Council on the bacterial treatment of sewage. Interesting as this report must prove to all those who peruse it, perhaps the most remarkable feature in connection with it is the information which it does not contain.

Dr. Clowes was evidently desirous of eliciting facts and figures from all the leading towns, where the bacterial treatment of sewage has been installed. It would appear that information was sought from forty-seven towns and the replies are arranged in tabular form. There are two columns in the table, the headings of which are of the greatest possible interest, both to the Engineer and to the ratepayer. Namely: (1) "the actual or estimated cost of making the beds;" (2) "cost of treating sewage per million gallons."

Here at last the sanitarian hoped to find information from which some averages could be deduced. These hopes are far from being realised. It 
is true that as regards the cost per acre of making the beds some very valuable figures are furnished, although only twenty-three of the towns replied to the question.

Taking an average of the whole twenty-three towns, it appears that the average cost per acre of making the beds is $£ 4,241$. This figure is even greater than that given by the author at Sonthampton, and emphasises the opinion which he has frequently expressed on the subject of the cost of bacterial treatment. If two acres of beds are allowed for every million gallons treated per day the interest and sinling fund on the expenditure will be over $\mathfrak{E} 400$ per annum, and more than $\mathfrak{E} 1$ per million gallons treated per diem. As far as can be gathered from Dr. Clowes' Tables these figures do not include the cost of the open septic tanks in the cases where they are used. When it is remembered that to get the best results this tank capacity should be at least equal to the daily flow, it becomes evident that this factor cannot be ignored, neither can the absence of any reply from twenty-four towns escape attention.

But if these figures are instructive, the absence of almost all information under the heading "Cost of treating sewage per million gallons" is still more striking. Out of the forty-seven towns only nine made any attempt to reply to the question, and the replies which were given are so incomplete and contradictory as to be valueless.

Of the nine towns, four were using chemicals for precipitating solids prior to the bacterial treatment, and the figure in each of these cases is apparently the cost of the chemical treatment and not that of the bacterial treatment. In one other town, namely Aylesbury, the cost is put down at the startling figure of $£ 1 j$ per million gallons treated, while Salford is put down at $16 \mathrm{~s}$. What is to be inferred from these contradictory replies and from the ominous silence of the thirty-eight other towns?

There can be only two answers to this question. Either the actual total cost of the bacterial treatment of sewage in these towns-which should, of course, include interest and sinking fund on the capital outlay as well as working expenses and renewals -is not known, or, if it has been ascertained, the officials whose duty it was to furnish the returns do not care to make the figures public.

Surely if such a great saving is being effected in the rates of these towns as that which $\mathrm{Mr}$. Dibdin has assured us will result from the adoption of bacterial treatment, it is only fair to the rest of the community that the good news should be proclaimed.

In 1884 the Commission on Metropolitan Sewage Discharge reported 
that the cost of treating sewage in tanks and by chemicals was about $£ 1,500$ per annum for each million gallons per day, or a little under ono shilling per head per annum.

With all the facts and figures which are available, and in view of the conspiracy of silence among the towns that have been categorically examined on the point, will anyone yet venture to affirm that bacterial treatment, whatever be its other merits, is much more economical than the systems which preceded it? The present position of the sewarge problem seems to show that althougl substantial progress in the quality of the effluent has been made, the best results are not obtainerl without great capital expenditure and great care in management, while sludge clisposal, the "bite noire of the sanitarian," is not yet a thing of the past.

(For discussion on this paper, see page 352.) 